\title{
FORMULASI DAN UJI EFEKTIVITAS GEL DAN SALEP MINYAK KEMANGI (Ocimum basilicum Linn) TERHADAP BAKTERI Staphylococcus aureus
}

\author{
Ririn, Iskandar Zulkarnain, Siska Natsir \\ Fakultas Farmasi Universitas Muslim Indonesia, Makassar \\ Email : ririnrays@gmail.com.
}

\begin{abstract}
Basil is one of a plant that has antibacterial activity on Staphylococcus aureus, the cause of furuncle. To cure the desease it is require preparations with a good penetrability, i.e gels and ointments. The goal of the research was to obtained the most stable both gel and ointment formulations of basil seed oil (Ocimum basilicum Linn.) pharmaceutically and effective microbiologically. Physical stability evaluations were performed by the parameters were organoleptic, viscosity measurement, homogeneity, spreadability, and flowing type at $5^{\circ} \mathrm{C}$ and $35^{\circ} \mathrm{C}$ for 12 hours on each temperature for 10 cycles. Organoleptic assay showed that there was no change in color, odor and concistency of all formula. Based on statistic analyses by Randomized design exhibited a significant change of gel and ointment formulation during storage. Homogeneity test showed that all formula possess even particle distribution. Based on rheogram exhibited thixotrophy-plastic flow type. Microbiological assay carried out by observe the formed inhibitory zone. Physical evaluation obtained formula II of gel was the most stable (12\% basil seed oil) and formula III of ointment (18\% basil seed oil) and microbiologically effective was formula III. While the most effective microbiologically in inhibit the growth of Staphylococcus aureus was gel preparation in $18 \%$ concentration of basil seed oil.
\end{abstract}

Keywords : Basil seed oil, Ocimum basilicum Linn, Antibacterial Activity, Staphylococcus aureus, Gel and Ointment preparation.

\section{PENDAHULUAN}

Kemangi merupakan salah satu dari keanekaragaman hayati yang memiliki potensi untuk dikembangkan sebagai obat tradisonal. Di masyarakat, kemangi sejak dahulu sudah digunakan untuk mengobati berbagai penyakit seperti perut kembung atau masuk angin, demam, melancarkan Air Susu lbu (ASI), rematik, sariawan, antibakteri dan juga sebagai antijamur. Bagian dari tanaman kemangi yang banyak digunakan adalah daunnya. Dalam 
Formulasi Dan Uji Efektivitas Gel Dan Salep Minyak Kemangi (Ocimum basilicum Linn) Terhadap Bakteri Staphylococcus aureus.

penggunaannya, daun kemangi sering disuling dan diambil kandungan minyak atsirinya. Minyak atsiri kemangi mempunyai kandungan senyawa dominanseperti linalool, metilklavikol (estragol), 1-8 sineol, eugenol, terpineol, geraniol. Dimana minyak atsiri dari daun kemangi berperan sebagai antibakteri. Hasil studi yang diungkapkan Opalchenovaa and Obreshkovab pada Juli 2003 menyatakan bahwa minyak atsiri dari kemangi menghambat jenis bakteri Staphylococcus, Enterococcus dan Pseudomonas (1). Selain bakteri, minyak atsiri daun kemangi juga mampu menghambat pertumbuhan jamur seperi Aspergillus flavus, Candida albicans, Rhizopus stolinifera, dan Penicillium digitatum (2).

Bisul (furuncle) adalah nodul nyeri hebat yang terbentuk dalam kulit oleh peradangan terbatas dari korium dan jaringan subkutis, mengelilingi nekrosis sentral atau "inti"; disebabkan oleh Staphylococcus yang memasuki kulit melalui folikel rambut.Nodulanodula ini dalam beberapa hari akan terisi cairan dan mengeluarkan bahan nekrotik bernanah. Furunkel dapat menimbulkan nyeri hebat bila terletak di daerah hidung, aksila, atau telinga (3-4).

Untuk mengatasi masalah bisul, dibutuhkan suatu sediaan yang mempunyai daya penetrasi yang baik dan waktu kontak yang cukup lama untuk mengurangi atau mengobati bisul. Dua diantaranya adalah sediaan gel dan salep. Keuntungan dari sediaan gel yaitu mempunyai kadar air yang tinggi sehingga dapat menghidrasi stratum corneum. Hal ini menyebabkan pori-pori kulit akan terbuka sehingga suatu sediaan mampu berpenetrasi masuk melalui lapisan kulit. Sediaan gel juga cenderung lembut, elegan dan menghasilkan efek pendinginan karena evaporasi dari air.Sediaan gel juga dapat mengering untuk membentuk film. Film melekat dengan baik pada kulit dan biasanya mudah dihilangkan dengan pencucian. Selain itu mengurangi resiko timbulnya peradangan lebih lanjut akibat menumpuknya minyak dalam poripori. Sedangkan sediaan salep digunakan sebagai pembawa untuk obat yang dimaksudkan untuk menghasilkan efek farmakologi di, atau dekat aplikasi yang dituju (5). Hasil orientasi penelitian yang telah dilakukan menunjukkan bahwa minyak kemangi (Ocimum basilicum Linn) memiliki aktivitas antibakteri terhadap Staphylococcus aureus dengan nilai KHM 6\%. 
Formulasi Dan Uji Efektivitas Gel Dan Salep Minyak Kemangi (Ocimum basilicum Linn) Terhadap Bakteri Staphylococcus aureus.

Berdasarkan hasil orientasi penelitian minyak atsiri kemangi yang memiliki aktivitas antibakteri terhadap Staphylococcus aureus, peneliti bermaksud melakukan penelitian mengenai Formulasi Sediaan Gel dan Salep dari Minyak Kemangi (Ocimum basilicum Linn) sebagai obat antibisul dan Uji Efektivitasnya terhadap Bakteri Staphylococcus aureus.

\section{METODE PENELITIAN}

Bahan : Air suling, alfa tokoferol, cera alba, karbopol®940 BF Goodrich, metil paraben, medium NA (Nutrient Agar), minyak daun kemangi (Ocimum basilucum Linn), Paper disc, propilenglikol, propil paraben, trietanolamin (TEA), Tween 80®.

Metode. Rancangan Formula Gel dan Salep Minyak Kemangi (Ocimum basilicum Linn)

Gel minyak kemangi dibuat dengan bahan pembentuk gel yaitu karbopolß940 BF Goodrich,air suling digunakan sebagai pelarut, metil paraben sebagai pengawet, propilenglikol sebagai humektan, alfa tokoferol sebagai antioksidan, TEA sebagai penetralkarbopol®940 BF Goodrich, dan Tween 80®sebagai surfaktan, dan minyak kemangi (Ocimum basilicum Linn) sebagai bahan aktif. Dirancang formula salep basis hidrokarbon dengan menggunakan basis cera alba dan vaselin putih, propil paraben sebagai pengawet, alfa tokoferol sebagai antioksidan fase minyak dan minyak kemangi (Ocimum basilicum Linn) sebagai bahan aktif.

\section{Uji Aktivitas Antimikroba Minyak} Kemangi (Ocimum basilicum Linn) Terhadap Bakteri Staphylococcus aureus

Dibuat empat seri konsentrasi minyak kemangi dari larutan stok $10 \%$ $\mathrm{v} / \mathrm{v}$ yang mengandung pelarut PEG 400 yaitu $0,1 \%$, 1\%, 10\%, dan $100 \%$. Dibuat kontrol PEG 400. Masingmasing konsentrasi dimasukkan ke dalam vial dan dimasukkan paper disc dan direndam selama \pm 1 jam. Diambil suspensi bakteri Staphylococcus aureussebanyak 1 ose kemudiaan dimasukkan ke dalam vial, lalu ditambahkan medium sebanyak 10 $\mathrm{mL}$, dihomogenkan. Medium yang mengandung suspensi bakteri Staphylococcus aureus tersebut dituang ke dalam cawan petri dan ditungguhingga memadat. Setelah medium memadat, paper disc yang telah direndam sebelumnya ditanam di dalam cawan petri yang berisi medium. Diinkubasi selama 1x24 jam. Diamati zona hambatnya. Dilakukan hal yang sama untuk uji aktivitas 
Formulasi Dan Uji Efektivitas Gel Dan Salep Minyak Kemangi (Ocimum basilicum Linn) Terhadap Bakteri Staphylococcus aureus.

antimikroba minyak kemangi dengan menggunkan konsentrasi $2 \%, 4 \%, 6 \%$, $8 \%$, dan $10 \%$.

\section{Pembuatan Gel dan Salep Minyak} Kemangi (Ocimum basilicum Linn)

Pembuatan sediaan gel minyak kemangi (Ocimum basilicum Linn)

Formulasi gel minyak kemangi dibuat dengan menggunakan basis karbopol.. Metil paraben dilarutkan dengan cara dimasukkan ke dalam air suling dan dipanaskan hingga suhu $70^{\circ} \mathrm{C}$. Setelah metil paraben larut, dimasukkan karbopol® dan didispersikan. Setelah iu ditambahkan TEA untuk menetralkan karbopol. Kemudiaan diaduk hingga membentuk gel yang transparan. Gel karbopolß didiamkan selama 24 jam pada suhu kamar kemudian digerus. Ditambahkan propilenglikol dan minyak daun kemangi $6 \% \mathrm{v} / \mathrm{b}$, kemudian digerus hingga homogen. Setelah itu penggerusan dihentikan dan gel disimpan dalam wadah tertutup. Gel didiamkan selama 24 jam. Dilakukan hal yang sama untuk formulasi gel minyak kemangi dengan konsentrasi $12 \%$ v/b dan $18 \%$ v/b.

Formulasi salep minyak kemangi dibuat dengan menggunakan basis hidrokarbon.

Salep dengan basishidrokarbon dibuat dengan menggunakan metode peleburan, yaitu cera alba yang telah ditimbang, dipanaskan pada suhu $62^{\circ} \mathrm{C}$ hingga melebur, tambahkan propil paraben kemudian ditambahkan vaselin putih yang telah ditimbang lalu diaduk hingga homogen, ditambahkan alfa tokoferol dan diaduk hingga homogen setelah itu diangkat dari penangas, ditunggu hingga memadat. Setelah itu digerus dan dimasukkan minyak kemangi, lalu digerus hingga homogen menggunakan lumpang. Setelah itu disimpan selama 24 jam.

\section{Evaluasi Sediaan Gel dan Salep} Minyak Kemangi

(Ocimum basilicum Linn)

\section{Evaluasi kestabilan dengan kondisi dipaksakan}

Untuk menguji kestabilan dari produk yang diformulasi biasanya dilakukan dengan metode kondisi dipaksakan (stress condition) untuk mempercepat peruraian dan mengurangi waktu yang diperlukan untuk pengujian. Sediaan gel dan salep diuji kestabilannya pada suhu $5^{\circ} \mathrm{C}$ dan $35^{\circ} \mathrm{C}$ selama 10 siklus dimana tiap 1 siklus adalah 12 jam. Evaluasi dengan beberapa parameter kestabilan fisika. Evaluasi kestabilan fisika dari sediaan gel dan salep dilakukan dengan beberapa parameter fisika yaitu pengukuran viskositas, pengujian organoleptis , penentuan 
Formulasi Dan Uji Efektivitas Gel Dan Salep Minyak Kemangi (Ocimum basilicum Linn) Terhadap Bakteri Staphylococcus aureus.

nilai yield, penentuan tipe aliran, daya sebar, dan homogenitas.

\section{Pengujian organoleptik sediaan gel dan salep}

Pengujian organoleptik meliputi pemeriksaan perubahan bau, warna dan konsistensi dari formula sebelum dan sesudah kondisi dipaksakan.

Pengukuran viskositas sediaan dan penentuan tipe aliran gel dan salep

Sebanyak 50,0 $\mathrm{mL}$ sediaan gel dimasukkan ke dalam gelas ukur 50,0 $\mathrm{mL}$ kemudian diukur viskositasnya dengan menggunakan viskometer Brookfield RVT yang dilengkapi dengan spindle no.6 dengan kecepatan 50 rpm (putaran per menit) kemudian dicatat hasilnya. Evaluasi dilakukan terhadap masing-masing formula sebelum dan sesudah kondisi dipaksakan. Dilakukan hal yang sama untuk sediaan salep dengan menggunakan viskometer Brookfield RVT yang dilengkapi dengan spindle no.7. Untuk penentuan tipe aliran, dilakukan pengukuran viskositas gel dan salep pada berbagai rpm $(2,5,10$, 20, 50, dan 100 rpm). Kemudian diukur nilai yieldnya dengan menggunakan viskometer Brookfield RVT. Kemudian dicatat hasilnya. Evaluasi dilakukan terhadap masingmasing formula sebelum dan sesudah kondisi dipaksakan. Pengukuran untuk sediaan gel menggunaan spindel no. 6 sedangkan salep menggunakan spindel no.7.

\section{Pengujian Homogenitas}

Pengujian dilakukan dengan mengoleskan sediaan gel dan salep pada obyek gelas, kemudian ditutup dengan deck glass. Setelah itu diamati dengan menggunakan mikroskop perbesaran $40 \times 10$.

\section{Pemeriksaan daya sebar}

Sediaan sebanyak 200,0 mg diletakkan diatas kaca bening berdiameter $20 \mathrm{~cm}$, ditutup dengan kaca bening berdiameter $20 \mathrm{~cm}$, tebal $2 \mathrm{~mm}$ dan berat $147,42 \mathrm{~g}$. Diatasnya diberi beban sebesar $125 \mathrm{~g}, 225 \mathrm{~g}$, dan 325 g. Kemudiaan diukur diameter daya sebarnya.

\section{Pengujian Efektivitas Sediaan Gel dan Salep}

Minyak kemangi

(Ocimum basilicum Linn.) yang Stabil Terhadap Bakteri Staphylococcus aureus dengan metode difusi. Pengujian efektivitas sediaan gel dan salepminyak kemangi (Ocimum basilicum Linn.) dilakukan pada bakteri Staphylococcus aureus yang merupakan salah satu bakteri penyebab bisul. Pengujian dilakukan sebelum dan sesudah kondisi dipaksakan dengan menggunakan cawan petri yang berisi medium 
Formulasi Dan Uji Efektivitas Gel Dan Salep Minyak Kemangi (Ocimum basilicum Linn) Terhadap Bakteri Staphylococcus aureus.

nutrien agar (NA) dan satu ose Setelah itu diinkubasi selama 1 x 24 suspensi bakteri Staphylococcus jam dan diamati zona hambatannya aureus yang telah dihomogenkan dan dibiarkan memadat. Kemudiaan diambil paper disc yang sebelumnya telah dimasukkan masing-masing kedalam sediaangel dan salep minyak kemangi (Ocimum basilicum Linn.). yang terbentuk. Apabila terbentuk zona hambatan, maka sediaan gel dan salep dengan konsentrasi tersebut dapat dinyatakan efektif terhadap bakteri Staphylococcus aureus penyebab bisul.

\section{HASIL PENELITIAN}

\section{Evaluasi organoleptik gel dan salep}

Tabel 1. Hasil pengamatan organoleptis sediaan gel sebelum dan sesudah kondisi dipaksakan.

\begin{tabular}{cccc}
\hline \multirow{2}{*}{ Formula (Gel) } & \multirow{2}{*}{ Jenis pemeriksaan } & \multicolumn{2}{c}{ Kondisi } \\
\cline { 3 - 4 } & Bau & Sebelum & Sesudah \\
\hline \multirow{2}{*}{ F1 A } & Warna & Khas & Khas \\
& Konsistensi & Putih & Putih \\
& Bau & Kental & Kental \\
\hline \multirow{2}{*}{ F1 B } & Warna & Putih & Khas \\
& Konsistensi & Kental & Kental \\
\hline \multirow{2}{*}{ F1 C } & Bau & Khas & Khas \\
& Warna & Putih & Putih \\
& Konsistensi & Kental & Kental \\
\hline
\end{tabular}

Tabel 2. Hasil pengamatan organoleptis sediaan salep sebelum dan sesudah kondisi dipaksakan.

\begin{tabular}{cccc}
\hline \multirow{2}{*}{ Formula (Salep) } & \multirow{2}{*}{ Jenis pemeriksaan } & \multicolumn{2}{c}{ Kondisi } \\
\cline { 3 - 4 } & Bau & Sebelum & Sesudah \\
\hline \multirow{2}{*}{ F2 A } & Warna & Khas & Khas \\
& Konsistensi & Kuning gading & Kuning gading \\
& Bau & Kental & Khas \\
\hline \multirow{2}{*}{ F2 B } & Warna & Kuning gading & Kuning gading \\
& Konsistensi & Kental & Kental \\
\hline \multirow{2}{*}{ F2C } & Bau & Khas & Khas \\
& Warna & Kuning gading & Kuning gading \\
& Konsistensi & Kental & Kental \\
\hline
\end{tabular}


Formulasi Dan Uji Efektivitas Gel Dan Salep Minyak Kemangi (Ocimum basilicum Linn) Terhadap Bakteri Staphylococcus aureus.

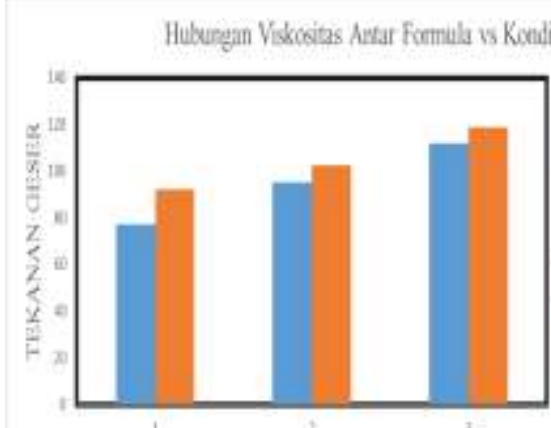

KFCEMTAX GESER
A

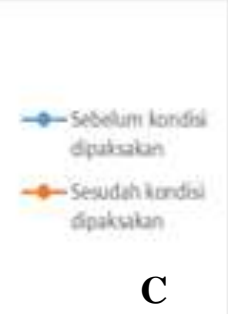

Hobungan Viskositas Astar Furmula is Kendis

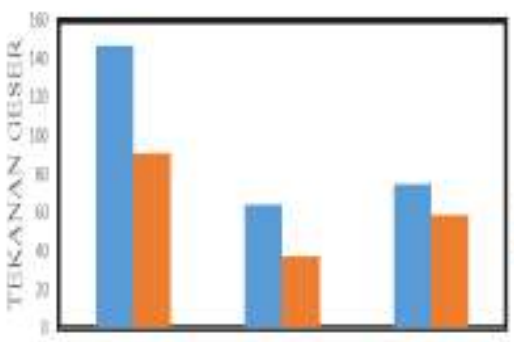

KECBMTAN GESER

B

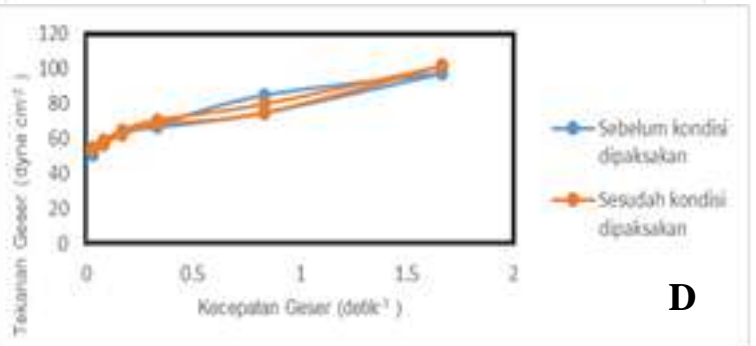

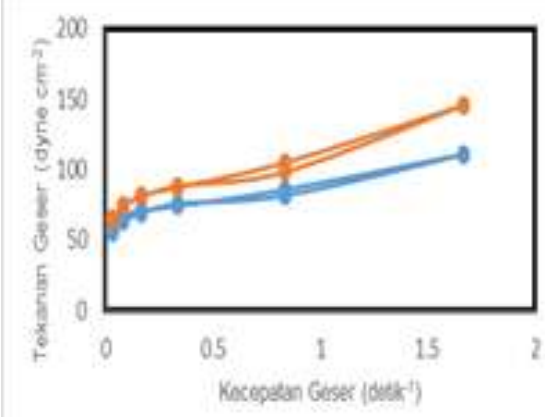
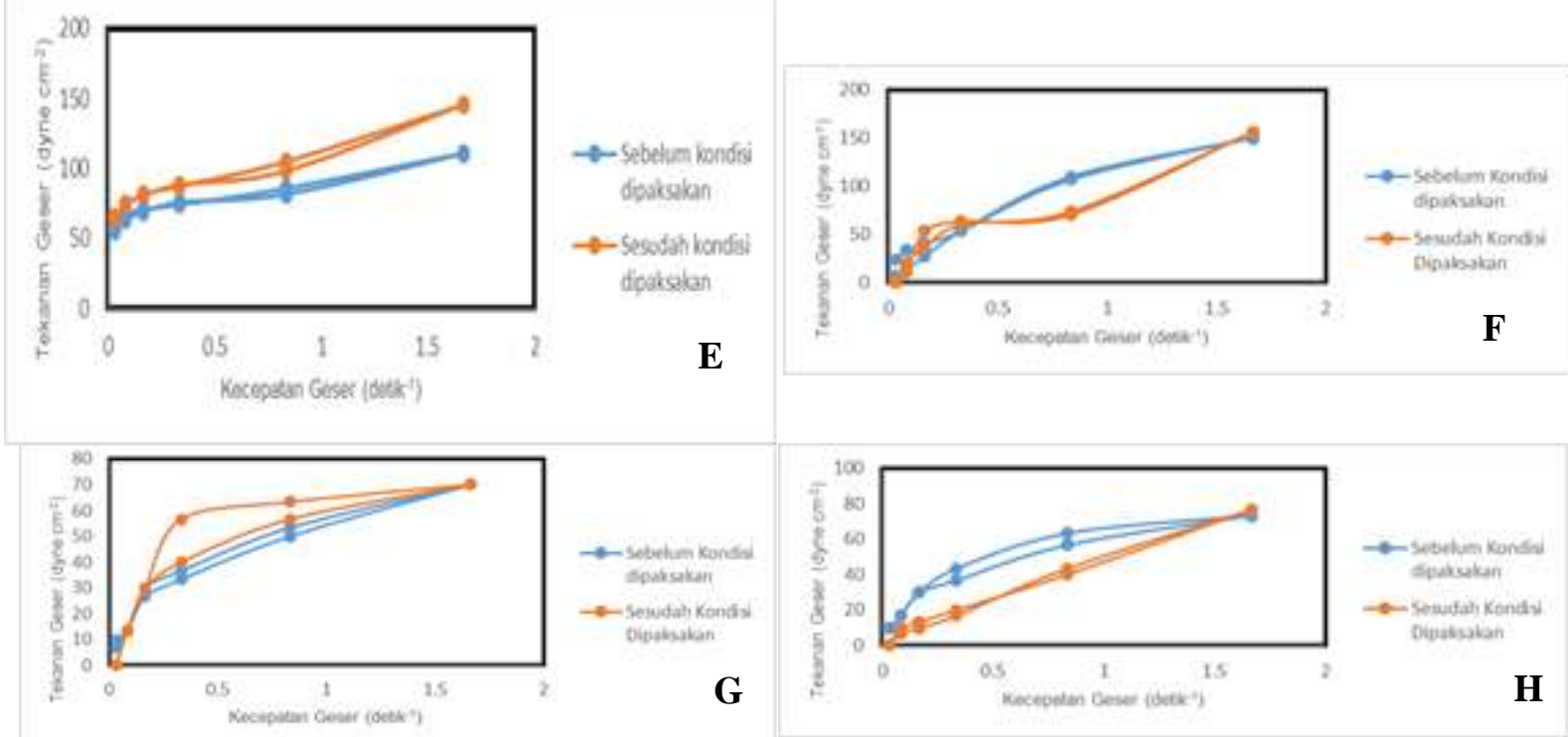

Gambar 1. Histogram dan rheogram gel dan salep minyak kemangi (Ocimum basilicum Linn.) sebelum dan sesudah kondisi dipaksakkan. Gambar 1A. Histogram viskositas gel. Gambar 1B. Histogram viskositas salep. Gambar 1C. Rheogram gel dengan Konsentrasi Minyak Kemangi 6\% (Stress condition). Gambar 1D. Rheogram Gel dengan Konsentrasi Minyak Kemangi 12\% (Stress condition). Gambar 1E. Rheogram Gel dengan Konsentrasi Minyak Kemangi 18\% (Stress condition).Gambar 1F. Rheogram Salep dengan Konsentrasi Minyak Kemangi 6\% (Stress condition). Gambar 1G. Rheogram Salep dengan Konsentrasi Minyak Kemangi 12\% (Stress condition). Gambar 1H. Rheogram Salep dengan Konsentrasi Minyak Kemangi 18\% (Stress condition). 
Formulasi Dan Uji Efektivitas Gel Dan Salep Minyak Kemangi (Ocimum basilicum Linn) Terhadap Bakteri Staphylococcus aureus.

Tabel 3. Tabel Hasil Pengukuran Viskositas (poise) Gel dari Minyak Kemangi (Ocimum basilicum Linn) pada 50 rpm dengan Menggunakan Viskometer Brookfield RVT dengan Spindel No. 6.

\begin{tabular}{|c|c|c|c|c|c|}
\hline \multirow{2}{*}{ Kondisi } & \multirow{2}{*}{ Replikasi } & \multicolumn{3}{|c|}{ Viskositas (poise) } & \multirow{2}{*}{ Total } \\
\hline & & F1A & F1B & F1C & \\
\hline & 1 & 78 & 95 & 112 & 285 \\
\hline \multirow[t]{2}{*}{ Sebelum } & 2 & 77 & 95 & 112 & 284 \\
\hline & 3 & 77 & 96 & 112 & 285 \\
\hline Sub total & & 232 & 286 & 336 & 854 \\
\hline \multirow{2}{*}{ Rata-rata } & & 77,333 & 95,333 & 112 & \\
\hline & 1 & 92 & 102 & 118 & 312 \\
\hline \multirow{2}{*}{ Sesudah } & 2 & 92 & 102 & 120 & 314 \\
\hline & 3 & 92 & 104 & 118 & 314 \\
\hline Sub total & & 276 & 308 & 356 & 940 \\
\hline Rata-rata & & 92 & 102,666 & 118,666 & \\
\hline Total & & 508 & 594 & 692 & 1794 \\
\hline
\end{tabular}

Tabel 4. Hasil Pengukuran Viskositas (poise) Salep dari Minyak Kemangi (Ocimum basilicum Linn) pada 50 rpm dengan Menggunakan Viskometer Brookfield RVT dengan Spindel No.7

\begin{tabular}{|c|c|c|c|c|c|}
\hline \multirow{2}{*}{ Kondisi } & \multirow{2}{*}{ Replikasi } & \multicolumn{3}{|c|}{ Viskositas(poise) } & \multirow{2}{*}{ Total } \\
\hline & & F2A & F2B & F2C & \\
\hline & 1 & 144 & 64 & 80 & 288 \\
\hline \multirow[t]{2}{*}{ Sebelum } & 2 & 144 & 64 & 72 & 280 \\
\hline & 3 & 152 & 64 & 72 & 288 \\
\hline \multicolumn{2}{|c|}{ Sub total } & 440 & 192 & 224 & 856 \\
\hline \multicolumn{2}{|c|}{ Rata-rata } & 146,666 & 64 & 74,666 & \\
\hline & 1 & 92 & 40 & 60 & 192 \\
\hline \multirow[t]{2}{*}{ Sesudah } & 2 & 96 & 36 & 60 & 192 \\
\hline & 3 & 84 & 36 & 56 & 176 \\
\hline \multicolumn{2}{|c|}{ Sub total } & 272 & 112 & 176 & 560 \\
\hline \multicolumn{2}{|c|}{ Rata-rata } & 90,666 & 37,333 & 58,666 & \\
\hline \multicolumn{2}{|c|}{ Total } & 712 & 304 & 400 & 1416 \\
\hline
\end{tabular}

Tabel 5. Hasil Pengukuran Daya Sebar Gel dan Salep dari Minyak Kemangi (Ocimum basilicum Linn. )

\begin{tabular}{ccccccc}
\hline Beban (gram) & \multicolumn{3}{c}{ Sediaan Gel $\mathbf{( c m )}$} & \multicolumn{3}{c}{ Sediaan Salep (cm) } \\
\cline { 2 - 7 } & F1A & F1B & F1C & F2A & F2B & F2C \\
\hline 125 & 3,8 & 4 & 4,1 & 3,6 & 3,9 & 4,3 \\
225 & 4,1 & 4,3 & 4,5 & 4 & 4,2 & 4,6 \\
325 & 4,3 & 4,5 & 4,9 & 4,1 & 4,5 & 4,9 \\
Total & 12,2 & 12,8 & 13,5 & 11,7 & 12,6 & 13,8 \\
\hline
\end{tabular}


Formulasi Dan Uji Efektivitas Gel Dan Salep Minyak Kemangi (Ocimum basilicum Linn) Terhadap Bakteri Staphylococcus aureus.

Tabel 6. Hasil pengukuran zona hambatan gel dan salep dari minyak kemangi (Ocimum basilicum Linn. ) sebelum dan setelah kondisi dipaksakan pada Bakteri Uji Staphylococcus aureus

\begin{tabular}{|c|c|c|c|c|c|c|c|c|c|}
\hline \multirow{3}{*}{$\begin{array}{c}\text { Bakteri } \\
\text { Uji }\end{array}$} & \multirow{3}{*}{ Kondisi } & \multicolumn{8}{|c|}{ Diameter Zona Hambatan (mm) } \\
\hline & & \multicolumn{3}{|c|}{ Formula Gel } & \multicolumn{3}{|c|}{ Formula Salep } & \multirow{2}{*}{$\begin{array}{c}\text { Kontrol Gel } \\
\text { (tanpa } \\
\text { pengawet) }\end{array}$} & \multirow{2}{*}{$\begin{array}{c}\text { Kontrol Salep } \\
\text { (tanpa } \\
\text { pengawet) }\end{array}$} \\
\hline & & F1A & F1B & F1C & F2A & F2B & F2C & & \\
\hline$S$. & Sebelum & 10,6 & 11,6 & 13,6 & 13,6 & 16,6 & 17 & 13,6 & 7 \\
\hline aureus & Sesudah & 17,6 & 18,6 & 19 & 0 & 0 & 0 & 12,3 & 5,6 \\
\hline
\end{tabular}
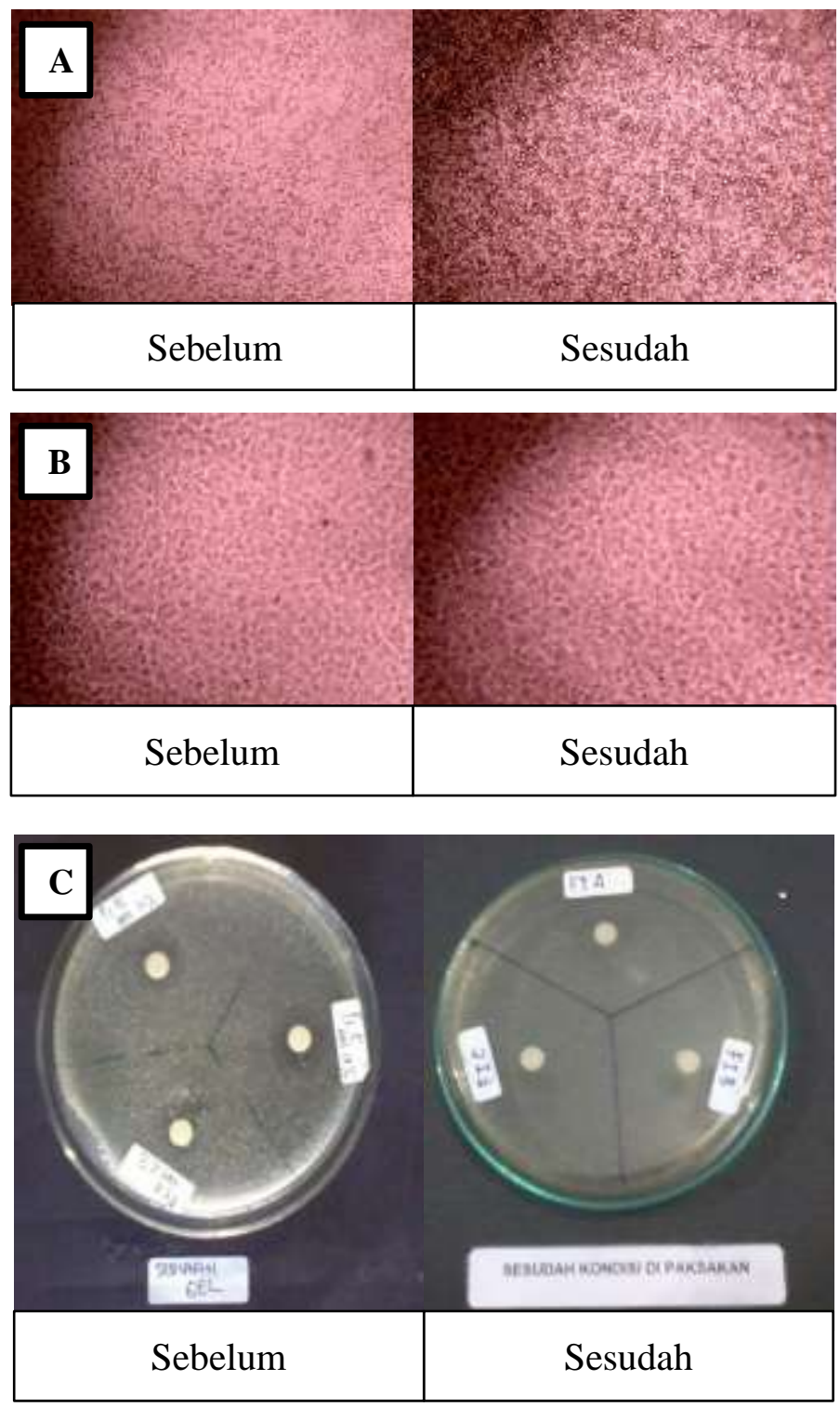

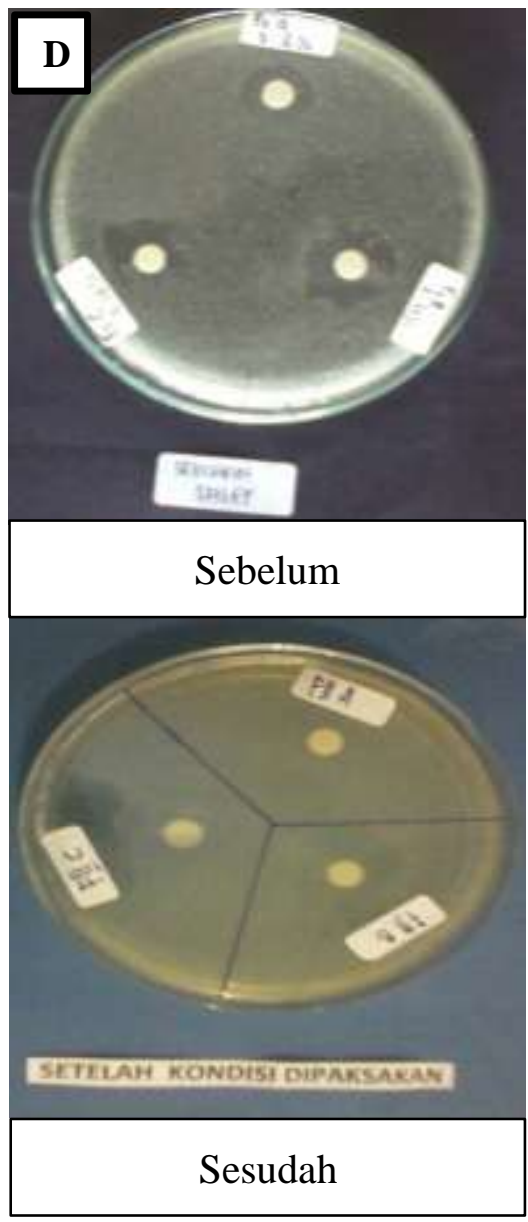

Sesudah

Gambar 9. Foto sediaan dan uji aktivitas antimikroba gel dan salep minyak kemangi (Ocimum basilicum Linn) pada Pengujian homogenitas Sebelum dan sesudah Kondisi dipaksakan. Gambar 9A. sediaan gel dengan konsentrasi minyak kemangi 12\%. Gambar 9B. sediaan salep dengan konsentrasi minyak kemangi 18\%. Gambar 9C. sediaan gel dari minyak kemangi terhadap bakteri Staphylococcus aureus. Gambar 9D. sediaan salep dari minyak kemangi terhadap bakteri Staphylococcus aureus. 
Formulasi Dan Uji Efektivitas Gel Dan Salep Minyak Kemangi (Ocimum basilicum Linn) Terhadap Bakteri Staphylococcus aureus.

PEMBAHASAN

Kemangi (Ocimum basilicum Linn.) merupakan salah satu dari keanekaragaman hayati yang memiliki potensi untuk dikembangkan sebagai obat tradisonal. Salah satunya yaitu dapat digunakan sebagai obat bisul karena memiliki aktivitas antibakteri terhadap Staphylococcus aureus. Untuk mengatasi bisul dibutuhkan sediaan yang mempunyai daya penetrasi yang baik dan waktu kontak yang lama. Dua diantaranya adalah sediaan gel dan salep. Di samping itu, masyarakat masa kini lebih cenderung mengharapkan teknik yang lebih mudah dalam menggunakan suatu sediaan. Dari hasil orientasi penelitian diperoleh nilai kadar hambat minimum (KHM) minyak kemangi (Ocimum basilicum Linn.) terhadap bakteri uji Staphylococcus aureus adalah 6\%v/v dengan diameter zona hambatan sebesar $13 \mathrm{~mm}$. Beberapa hal inilah yang melatarbelakangi peneliti untuk memformulasi minyak kemangi (Ocimum basilicum Linn.) ke dalam bentuk sediaan gel dan salep. Untuk memperoleh sediaan yang memiliki efektivias yang maksimal, maka sediaan gel dan salep dibuat dalam beberapa variasi konsentrasi zat aktif yang didukung dengan evaluasi kestabilan berdasarkan parameter tertentu.

Pada penelitian ini dibuat 2 sediaan, masing-masing sediaan dibuat dalam 3 formula dengan konsentrasi minyak kemangi yang berbeda $6 \%$, $12 \%$, dan $18 \%$. Selanjutnya dilakukan pengujian berdasarkan enam parameter diantaranya pemeriksaan organoleptik, pengukuran viskositas, penentuan tipe aliran, homogenitas, pemeriksaan daya sebar serta pengujian aktivitas antimikroba terhadap bakteri Staphylococcus aureus. Pengujian kestabilan dilakukan dengan metode kondisi dipaksakan yang bertujuan untuk mempersingkat waktu pengujian.

Pemeriksaan organoleptik dilakukan untuk mengetahui pengaruh penyimpanan pada warna, bau dan konsistensi sediaan. Pemeriksaan organoleptik dilakukan untuk mengetahui ada tidaknya pengaruh penyimpanan pada warna, bau dan konsistensi sediaan. Adapun hasil pengamatan yang diperoleh dari ketiga formula geldan ketiga formula salep dari minyak kemangi (Ocimum basilicum Linn.) sebelum dan sesudah kondisi dipaksakan tidak mengalami perubahan dari segi warna, bau dan konsistensi. 
Formulasi Dan Uji Efektivitas Gel Dan Salep Minyak Kemangi (Ocimum basilicum Linn) Terhadap Bakteri Staphylococcus aureus.

Data viskositas yang diperoleh dianalisa secara statistik dengan menggunakan metode rancangan acak kelompok (RAK). Hasil analisis menunjukkan bahwa untuk sediaan gel, viskositas dari semua formula baik formula A, B, dan C dengan konsentrasi minyak kemangi $6 \%, 12 \%$ dan $18 \%$ mengalami perubahan yang sangat signifikan pada kondisi sebelum dan sesudah kondisi dipaksakan. Hal ini menunjukkan bahwa adanya kondisi dipaksakan sangat mempengaruhi viskositas semua formula.Kemudian dilakukan uji lanjutan menggunakan BNJ (Beda Nyata Jujur) karena nilai koefisien keragaman kurang dari $5 \%$ yaitu 1,4498877\%.

Pada uji lanjutan BNJ diperoleh hasil yaitu semua formula baik formula A, B, dan C dengan konsentrasi minyak kemangi $6 \%, 12 \%$ dan $18 \%$ mengalami perubahan yang sangat signifikan, baik pada kondisi sebelum maupun sesudah kondisi dipaksakan. Kemungkinan hal ini disebabkan karena adanya pengaruh suhu terhadap perubahan polimer. Dimana ketika suatu gel disimpan pada suhu panas maka bentuk rantai polimer akan melepaskan gulungan yang berbentuk bola (disentangle) mengakibatkan penurunan viskositas gel. Sedangkan pada suhu dingin rantai polimer akan memendek dan akan saling bergabung dan lama kelamaan gel akan mengkisut (entangle) sehingga terjadi perubahan viskositas setelah kondisi dipaksakan. Untuk sediaan salep, viskositas dari semua formula baik formula $A, B$, dan $C$ dengan konsentrasi minyak kemangi $6 \%, 12 \%$ dan $18 \%$ mengalami perubahan yang sangat signifikan pada kondisi sebelum dan sesudah kondisi dipaksakan .Kemudian dilakukan uji lanjutan menggunakan BNT (Beda Nyata Terkecil) karena nilai koefisien keragaman diantara 5$10 \%$ yaitu $8,679261 \%$.

Pada uji lanjutan BNT diperoleh hasil yaitu pada formula $A$ dengan konsentrasi minyak kemangi $6 \%$ dan formula $\mathrm{B}$ dengan konsentrasi minyak kemangi $12 \%$ mengalami perubahan yang sangat signifikan, sedangkan formula $\mathrm{C}$ dengan konsentrasi minyak kemangi $18 \% \quad$ menunjukkan perubahan yang tidak signifikan baikpada kondisi sebelum maupun sesudah kondisi dipaksakan.

Tipe aliran dapat dilihat dari reogram serta nilai yield sediaan. Dari rheogram diperoleh sifat aliran non newton untuk formula gel dan salep dengan konsentrasi minyak kemangi $6 \%$, $12 \%$, dan $18 \%$ memiliki aliran 
Formulasi Dan Uji Efektivitas Gel Dan Salep Minyak Kemangi (Ocimum basilicum Linn) Terhadap Bakteri Staphylococcus aureus.

thiksotropik-plastis. Aliran thiksotropik karena aliran menaik dan menurunnya tidak berimpitan sehingga terbentuk hysteresis loup (adanya celah yang terbentuk diantara kurva menaik dan menurun).

Untuk pengujian homogenitas, pengujian ini dilakukan untuk melihat distribusi partikel dari sediaan gel dan salep. Hasil yang diperoleh menunjukkan bahwa sediaan gel maupun salep sebelum dan sesudah kondisi dipaksakan memiliki partikel yang terdistribusi secara merata (tidak dilampirkan, kecuali sediaan gel dengan konsentrasi minyak kemangi $12 \%$ dan salep dengan konsentrasi minyak kemangi $18 \%$ )..

Dari hasil analisa terhadap kestabilan sediaan gel dan salep minyak kemangi (Ocimum basilicum Linn) sebelum dan setelah kondisi dipaksakan, untuk sediaan gel yang paling stabil secara farmasetik adalah formula B dengan konsentrasi minyak kemangi 12\%. Sedangkan untuk sediaan salep yang paling stabil secara farmasetik adalah formulaC dengan konsentrasi minyak kemangi $18 \%$.

Setelah dilakukan analisa terhadap kestabilan sediaan gel dan salep dari minyak kemangi (Ocimum basilicum Linn) dilakukan pengujian efektivitas dari masing-masing sediaan gel dan salep terhadap bakteri uji Staphylococcus aureus dengan metode difusi agar sebelum dan sesudah kondisi dipaksakan, sehingga bisa diamati ada tidaknya zoba hambatan yang terbentuk. Zona hambatan adalah daerah bening yang terbentuk disekeliling paper disk yang menunjukkan adanya penghambatan terhadap aktivitas mikroorganisme. Semakin besar zona hambatan yang terbentuk, berarti semakin besar daya penghambatannya terhadap mikroorganisme.

Berdasarkan hasil yang diperoleh maka dapat dikatakan bahwa sediaan yang paling efektif dalam menghambat pertumbuhan bakteri Staphylococcus aureus adalah sediaan gel dibandingkan sediaan salep. Hal ini disebabkan karena perbedaan polaritas minyak kemangi dengan basis gel. Sebaliknya pada salep, karena polaritas antara basis salep dengan minyak kemangi sama, maka afinitas basis salep terhadap minyak kemangi kuat sehingga basis susah melepaskan minyak kemangi. Selain itu, dilihat dari setelah kondisi dipaksakan, sediaan gel masih memberikan zona hambatan dibandingkan dengan sediaan salep. 
Formulasi Dan Uji Efektivitas Gel Dan Salep Minyak Kemangi (Ocimum basilicum Linn) Terhadap Bakteri Staphylococcus aureus.

\section{KESIMPULAN}

Secara farmaseutika, sebelum dan sesudah kondisi dipaksakan untuk sediaan gel yang paling stabil adalah formula B dengan konsentrasi minyak kemangi $12 \%$, sedangkan untuk sediaan salep yang paling stabil adalah formula $\mathrm{C}$ dengan konsentrasi minyak kemangi 18\%. Dan Secara mikrobiologi, sebelum dan sesudah kondisi dipaksakan sediaan yang paling efektif dalam menghambat pertumbuhan bakteri Saphylococcus aureus adalah sediaan gel dengan konsentrasi minyak kemangi 18\% dibandingkan dengan sediaan salep.

\section{DAFTAR PUSTAKA}

1. Opalchenovaa D, Obreshkovab D. Comparative studies on the activity of basil-an essential oil from Ocimum basilicum L. gainst multidrug resistant clinical isolates of the genera Staphylococcus, Enterococcus and Pseudomonas by using different test methods.J Micro Meth 2003; 54:105-110.

2. Rahmawati A. Uji Aktivitas Daya Antibakeri Daun Kemangi (Ocimum basilicum Linn) terhadap bakteri Eschercia coli dan Staphylococcus aureus secara invitro. (Skripsi). Surakarta:

Universitas Muhammadiyah, 2010.

3. Novak DP. Kamus Saku Kedokteran Dorland. Jakarta : Penerbit Buku Kedokteran EGC, 1998.

4. Price AS, Wilson ML. Patofisiologi : Konsep Klinis Proses-proses Penyakit. Jakarta : EGC, 2006.

5. Lund Walter. The Pharmaceutical Codex : Principles and Practice of Pharmaceutics. Twelfth Edition. London : The Pharmaceutical Presss, 1994.. 